Brit. J. industr. Med., 1962, 19, 180.

\title{
PREVALENCE OF RESPIRATORY DISEASE IN A FLAX MILL IN THE UNITED STATES*
}

\author{
BY \\ B. G. FERRIS, Jr., DONALD O. ANDERSON, and W. A. BURGESS \\ From the Division of Environmental Hygiene and Department of Epidemiology, \\ Harvard School of Public Health, Boston, Massachusetts $\dagger$
}

(RECEIVED FOR PUBLICATION NOVEMBER 17, 1961)

\begin{abstract}
Studies were made on 161 flax-mill workers at work by means of a questionnaire similar to that developed by the Medical Research Council and by means of simple pulmonary function tests. Air samples were obtained at various working sites. In this group of workers the effect of cigarette smoking as a factor in the production of chronic non-specific respiratory disease far outweighed the occupational exposures to dust or the effect of age in the males. There were insufficient diseased females for statistical analysis.
\end{abstract}

The high mortality due to chronic bronchitis and emphysema in Great Britain has stimulated a number of studies to determine the prevalence of various respiratory symptoms in different populations. Little work of this sort has been done thus far in the United States except for Pemberton's studies (Pemberton and Macleod, 1956; Pemberton, 1956). Because of the reported low mortalities due to chronic bronchitis and emphysema in the United States, a study of the prevalence of respiratory symptoms comparable to those done in Great Britain would be of value and might indicate where further investigations were warranted. These data could be used for international comparisons as suggested by Reid (1960).

Schilling (1956) reported a high prevalence of byssinosis in cotton and other textile workers in England, and Mair, Smith, Wilson, and Lockhart (1960) have reported byssinosis in flax workers. Thus a study of the prevalence of respiratory symptoms in flax workers appeared to be an appropriate area to begin such a study in the United States.

\section{Methods}

The prevalence of respiratory symptoms in mill and office workers in a flax mill in central Massachusetts was determined in the summer of $\mathbf{1 9 6 0}$. There was little air pollution and the community was more rural than urban.

*This paper was delivered at the 4th International Epidemiological Association meeting at Korcula, August 26 to September 2, 1961.

†This study was aided in part by U.S. Public Health Service Grant OH-67 (formerly RG-7631).
The individuals available and those surveyed are shown in Table 1. The three refusals were all female workers. The five females and three males absent were ill or had illness in the family. Three shifts were operating and the survey was conducted at the mill during working hours.

A questionnaire similar to that developed by the Medical Research Council (Fairbairn, Wood, and Fletcher, 1959), for chronic non-specific respiratory disease was used. The questions were asked as written and in the same order each time. All questioning was done by one observer (B.F.). The presence or absence of chronic respiratory disease was based on the answers to the questions and the results of pulmonary function tests. The criteria used for the presence of chronic disease were any one or a combination of the following:

1. Productive cough in the morning or at least four to six times during the day, for at least four days a week, for three months a year, and for three consecutive winters.

2. Presence of wheezing or whistling in the chest most days or nights.

3. Breathlessness in winter of grade 3 or greater (Fletcher, Elmes, Fairbairn, and Wood, 1959).

4. The presence of bronchial asthma diagnosed by a physician and present at the time of the survey.

5. One-second forced expiratory volume $\left(\mathrm{FEV}_{1 \cdot 0}\right)$ less than $60 \%$ of vital capacity.

Age, height, weight, and occupational histories were also obtained. Measurements of pulmonary function consisted of five forced vital capacity tracings with a Collins 6-litre "vitalometer", and five efforts with the Wright peak-flow meter. The last three recordings of each of these two series were averaged to obtain the "true" vital capacity, $\mathrm{FEV}_{1 \cdot 0}$, and peak expiratory flow. 
TABLE 1

WORKING POPULATION AT THE FLAX MILL

\begin{tabular}{c|ccc}
\hline Total on payroll & 172 & \\
$\begin{array}{c}\text { Absent } \\
\text { Refused }\end{array}$ & 8 & & \\
Total $\begin{array}{c}\text { surveyed } \\
\text { Men } \\
\text { Women }\end{array}$ & 90 & $161 \quad(94 \%)$ \\
\hline
\end{tabular}

The one-second forced expiratory volume was obtained from the vital capacity tracings after correction had been made for variations in the initial phase of the tracing. This was done by extrapolating the fastest portion of the expirogram to zero volume and measuring one second from this point. All volumes were corrected to body temperature and pressure and saturated with water vapour (BTPS). Predicted vital capacities were based on sex, age, and height and were obtained from the nomogram of Miller, Johnson, and Wu (1959).

Air samples were obtained in various working areas within the mill by means of a "hi-vol" sampler for approximately one hour. It sampled $40 \mathrm{cu}$. $\mathrm{ft}$. of air per minute. Particulate material was collected on a weighed pleated filter. The total weight of material collected was obtained by the increase in weight (weighings were done under standard conditions of temperature and humidity). Samples were taken for particle sizing and analysis as described by Silverman and Viles (1950). From these data, the occupational history, and making certain assumptions, the lifetime amount of dust inhaled was estimated. It was assumed that all the dust in the air was inhaled and retained. The workers were estimated to be breathing at a rate of 10 litres per minute, 40 hours per week, and 50 weeks per year. The amount of dust so inhaled and retained per year was computed for the various jobs. Admittedly this was not a true value but such an estimate did give some index of the relative degree of exposure, and changes in jobs could be taken into account.

TABLE 2

PREVALENCE OF CHRONIC NON-SPECIFIC RESPIRATORY DISEASE IN MALE FLAX-MILL WORKERS RELATED TO AGE AND SMOKING CATEGORY

\begin{tabular}{|c|c|c|c|c|c|c|c|}
\hline \multirow{2}{*}{$\begin{array}{l}\text { Current } \\
\text { Cigarette- } \\
\text { smoking } \\
\text { Category }\end{array}$} & & \multicolumn{4}{|c|}{ Age-group } & \multirow{2}{*}{$\begin{array}{l}\text { All } \\
\text { Cate- } \\
\text { gories }\end{array}$} & \multirow{2}{*}{$\begin{array}{c}\text { Diseased } \\
(\%)\end{array}$} \\
\hline & & $15-34$ & $35-44$ & $45-54$ & $55+$ & & \\
\hline Never smoked & $\begin{array}{l}\mathbf{T}^{*} \\
\mathbf{D}^{+}\end{array}$ & $\begin{array}{l}4 \\
0\end{array}$ & $\begin{array}{l}3 \\
1\end{array}$ & $\begin{array}{r}10 \\
2\end{array}$ & $\begin{array}{l}3 \\
0\end{array}$ & $\begin{array}{r}20 \\
3\end{array}$ & $15 \cdot 0$ \\
\hline Ex-smoker & $\begin{array}{l}\mathbf{T} \\
\mathbf{D}\end{array}$ & $\begin{array}{l}0 \\
0\end{array}$ & $\begin{array}{l}2 \\
0\end{array}$ & $\begin{array}{l}4 \\
2\end{array}$ & $\begin{array}{r}10 \\
0\end{array}$ & $\begin{array}{r}16 \\
2\end{array}$ & $12 \cdot 5$ \\
\hline 1 to $20 /$ day & $\begin{array}{l}\mathbf{T} \\
\mathbf{D}\end{array}$ & $\begin{array}{l}4 \\
1\end{array}$ & 1 & $\begin{array}{l}8 \\
2\end{array}$ & $\begin{array}{l}9 \\
2\end{array}$ & $\begin{array}{r}22 \\
6\end{array}$ & $27 \cdot 3$ \\
\hline$>20 /$ day & $\begin{array}{l}\mathbf{T} \\
\mathbf{D}\end{array}$ & $\begin{array}{l}6 \\
2\end{array}$ & $\begin{array}{l}4 \\
2\end{array}$ & $\begin{array}{r}14 \\
: \quad 7\end{array}$ & $\begin{array}{l}8 \\
6\end{array}$ & $\begin{array}{l}32 \\
17\end{array}$ & $53 \cdot 1$ \\
\hline All categories & $\begin{array}{l}\mathbf{T} \\
\mathbf{D}\end{array}$ & $\begin{array}{r}14 \\
3 \\
\end{array}$ & $\begin{array}{r}10 \\
\quad 4\end{array}$ & $\begin{array}{l}36 \\
13\end{array}$ & $\begin{array}{r}30 \\
8\end{array}$ & $\begin{array}{l}90 \\
28\end{array}$ & \\
\hline Diseased (\%) & & $21 \cdot 4$ & 40.0 & $36 \cdot 1$ & 26.7 & & $31 \cdot 1$ \\
\hline
\end{tabular}

TABLE 3

PREVALENCE OF CHRONIC NON-SPECIFIC RESPIRATORY DISEASE IN MALE FLAX-MILL WORKERS RELATED TO AGE AND YEARS OF DUST EXPOSURE

\begin{tabular}{|c|c|c|c|c|c|c|c|}
\hline \multirow{2}{*}{$\underset{\text { (years) }}{\text { Dust }}$} & & \multicolumn{4}{|c|}{ Age-group } & \multirow{2}{*}{$\begin{array}{l}\text { All } \\
\text { Cate- } \\
\text { gories }\end{array}$} & \multirow{2}{*}{$\begin{array}{c}\text { Diseased } \\
(\%)\end{array}$} \\
\hline & & $\overline{15-34}$ & $35-44$ & $45-54$ & $55+$ & & \\
\hline $0-9$ & $\begin{array}{l}\mathbf{T}^{*} \\
\mathbf{D}+\end{array}$ & $\begin{array}{r}10 \\
2\end{array}$ & $\begin{array}{l}4 \\
2\end{array}$ & $\begin{array}{l}4 \\
2\end{array}$ & $\begin{array}{l}4 \\
1\end{array}$ & 22 & 31.8 \\
\hline $10-19$ & $\begin{array}{l}\mathbf{T} \\
\mathbf{D}\end{array}$ & $\begin{array}{l}4 \\
1\end{array}$ & $\begin{array}{l}1 \\
0\end{array}$ & $\begin{array}{l}6 \\
4\end{array}$ & $\begin{array}{l}1 \\
0\end{array}$ & $\begin{array}{r}12 \\
5\end{array}$ & $41 \cdot 7$ \\
\hline $20-29$ & $\begin{array}{l}\mathbf{T} \\
\mathbf{D}\end{array}$ & $\begin{array}{l}0 \\
0\end{array}$ & $\begin{array}{l}5 \\
2\end{array}$ & $\begin{array}{r}10 \\
5\end{array}$ & $\begin{array}{l}4 \\
1\end{array}$ & $\begin{array}{r}19 \\
8\end{array}$ & $42 \cdot 1$ \\
\hline $30-39$ & $\begin{array}{l}\mathbf{T} \\
\mathbf{D}\end{array}$ & $\begin{array}{l}0 \\
0\end{array}$ & $\begin{array}{l}\mathbf{0} \\
\mathbf{0}\end{array}$ & $\begin{array}{r}15 \\
2\end{array}$ & $\begin{array}{l}9 \\
1\end{array}$ & $\begin{array}{r}24 \\
3\end{array}$ & $12 \cdot 5$ \\
\hline 40 & $\begin{array}{l}\mathbf{T} \\
\mathbf{D}\end{array}$ & $\begin{array}{l}\mathbf{0} \\
\mathbf{0}\end{array}$ & $\begin{array}{l}\mathbf{0} \\
\mathbf{0}\end{array}$ & $\begin{array}{l}1 \\
0\end{array}$ & $\begin{array}{r}12 \\
5\end{array}$ & $\begin{array}{r}13 \\
5\end{array}$ & $38 \cdot 5$ \\
\hline All categories & $\begin{array}{l}\mathbf{T} \\
\mathbf{D}\end{array}$ & $\begin{array}{r}14 \\
3\end{array}$ & $\begin{array}{r}10 \\
4\end{array}$ & $\begin{array}{l}36 \\
13\end{array}$ & $\begin{array}{r}30 \\
8\end{array}$ & $\begin{array}{l}90 \\
28\end{array}$ & \\
\hline Diseased $(\%)$ & & $21 \cdot 4$ & $40 \cdot 0$ & $36 \cdot 1$ & $26 \cdot 7$ & & $31 \cdot 1$ \\
\hline
\end{tabular}

\section{Results}

The prevalence of respiratory symptoms was related to age, sex, smoking habits, years of exposure to dust, and the estimated inhaled quantity of dust. These data for males are presented in Tables 2 to 5 . The female data (Table 6) contained so few diseased individuals that it was not possible to handle them statistically. The data concerning the air samples and analyses are presented in Table 7 .

\section{Discussion}

Inspection of the data obtained on males (Tables 2 to 5) reveals that the percentage of diseased

TABLE 4

PREVALENCE OF CHRONIC NON-SPECIFIC RESPIRATORY DISEASE IN MALE FLAX-MILL WORKERS RELATED TO SMOKING CATEGORY AND YEARS OF DUST EXPOSURE

\begin{tabular}{|c|c|c|c|c|c|c|c|}
\hline \multirow{2}{*}{$\underset{\text { (years) }}{\substack{\text { Dust } \\
\text { (yposure }}}$} & & \multicolumn{4}{|c|}{$\begin{array}{l}\text { Current Cigarette- } \\
\text { smoking Category }\end{array}$} & \multirow{2}{*}{$\begin{array}{c}\text { All } \\
\text { Cate- } \\
\text { gories }\end{array}$} & \multirow{2}{*}{$\begin{array}{c}\text { Diseased } \\
(\%)\end{array}$} \\
\hline & & $\overline{\text { Never }}$ & $\begin{array}{c}\text { Ex- } \\
\text { smoker }\end{array}$ & $\begin{array}{l}1-20 \\
\text { /day }\end{array}$ & $\begin{array}{l}>20 i \\
\text { day }\end{array}$ & & \\
\hline $0-9$ & $\begin{array}{l}\mathbf{T}^{*} \\
\mathbf{D}^{+}\end{array}$ & $\begin{array}{l}5 \\
1\end{array}$ & $\begin{array}{l}4 \\
0\end{array}$ & $\begin{array}{l}7 \\
4\end{array}$ & $\begin{array}{l}6 \\
2\end{array}$ & 22 & $31 \cdot 8$ \\
\hline $10-19$ & $\begin{array}{l}\text { T } \\
\text { D }\end{array}$ & 2 & $\begin{array}{l}1 \\
0\end{array}$ & 2 & $\begin{array}{l}7 \\
4\end{array}$ & $\begin{array}{r}12 \\
5\end{array}$ & $41 \cdot 7$ \\
\hline $20-29$ & $\begin{array}{l}\mathbf{T} \\
\mathbf{D}\end{array}$ & $\begin{array}{l}5 \\
2\end{array}$ & $\begin{array}{l}5 \\
2\end{array}$ & $\begin{array}{l}2 \\
0\end{array}$ & $\begin{array}{l}7 \\
4\end{array}$ & $\begin{array}{r}19 \\
8\end{array}$ & $42 \cdot 1$ \\
\hline $30-39$ & $\begin{array}{l}\mathbf{T} \\
\mathbf{D}\end{array}$ & $\begin{array}{l}6 \\
0\end{array}$ & $\begin{array}{l}4 \\
0\end{array}$ & $\begin{array}{l}6 \\
0\end{array}$ & $\begin{array}{l}8 \\
3\end{array}$ & $\begin{array}{r}24 \\
3\end{array}$ & $12 \cdot 5$ \\
\hline 40 & $\begin{array}{l}\mathbf{T} \\
\mathbf{D}\end{array}$ & $\begin{array}{l}2 \\
0\end{array}$ & 2 & $\begin{array}{l}5 \\
1\end{array}$ & $\begin{array}{l}4 \\
4\end{array}$ & $\begin{array}{r}13 \\
5\end{array}$ & $38 \cdot 5$ \\
\hline All categories & $\begin{array}{l}\mathbf{T} \\
\mathbf{D}\end{array}$ & $\begin{array}{r}20 \\
3\end{array}$ & $\begin{array}{r}16 \\
2\end{array}$ & 22 & $\begin{array}{l}32 \\
17\end{array}$ & $\begin{array}{l}90 \\
28\end{array}$ & \\
\hline Diseased (\%) & & 15.0 & 12.5 & $27 \cdot 3$ & $53 \cdot 1$ & & $31 \cdot 1$ \\
\hline
\end{tabular}


TABLE 5

PREVALENCE OF CHRONIC NON-SPECIFIC RESPIRATORY DISEASE IN MALE FLAX-MILL WORKERS RELATED TO ESTIMATED LIFETIME GRAMS OF DUST INHALED AND SMOKING CATEGORY

\begin{tabular}{|c|c|c|c|c|c|c|c|}
\hline \multirow{2}{*}{$\underset{\substack{\text { Dust } \\
\text { Inhaled } \\
(\mathrm{g} .)}}{\text {. }}$} & & \multicolumn{4}{|c|}{$\begin{array}{l}\text { Current Cigarette- } \\
\text { smoking Category }\end{array}$} & \multirow{2}{*}{$\begin{array}{l}\text { All } \\
\text { Cate- } \\
\text { gories }\end{array}$} & \multirow{2}{*}{$\begin{array}{c}\text { Diseased } \\
(\%)\end{array}$} \\
\hline & & Never & \begin{tabular}{|c|} 
Ex- \\
smoker
\end{tabular} & $\begin{array}{l}1-20 \\
/ \text { day }\end{array}$ & $\begin{array}{r}>20 \\
\text { /day }\end{array}$ & & \\
\hline $0-5$ & $\begin{array}{l}\mathbf{T}^{*} \\
\mathbf{D}+\end{array}$ & $\begin{array}{l}5 \\
0\end{array}$ & $\begin{array}{l}1 \\
0\end{array}$ & $\begin{array}{l}4 \\
2\end{array}$ & $\begin{array}{l}6 \\
2\end{array}$ & $\begin{array}{r}16 \\
4\end{array}$ & $25 \cdot 0$ \\
\hline $6-19$ & $\begin{array}{l}T \\
\mathbf{D}\end{array}$ & $\begin{array}{l}3 \\
1\end{array}$ & $\begin{array}{l}4 \\
0\end{array}$ & $\begin{array}{l}5 \\
3\end{array}$ & $\begin{array}{l}8 \\
5\end{array}$ & $\begin{array}{r}20 \\
9\end{array}$ & $45 \cdot 0$ \\
\hline 20-39 & $\begin{array}{l}\text { T } \\
\mathbf{D}\end{array}$ & $\begin{array}{l}6 \\
2\end{array}$ & $\begin{array}{l}3 \\
1\end{array}$ & $\begin{array}{l}5 \\
0\end{array}$ & $\begin{array}{l}6 \\
4\end{array}$ & $\begin{array}{r}20 \\
7\end{array}$ & $35 \cdot 0$ \\
\hline $40-59$ & $\begin{array}{l}T \\
D\end{array}$ & $\begin{array}{l}3 \\
0\end{array}$ & $\begin{array}{l}1 \\
0\end{array}$ & $\begin{array}{l}0 \\
0\end{array}$ & $\begin{array}{l}6 \\
2\end{array}$ & $\begin{array}{r}10 \\
2\end{array}$ & $20 \cdot 0$ \\
\hline $60-79$ & $\begin{array}{l}\mathrm{T} \\
\mathbf{D}\end{array}$ & $\begin{array}{l}1 \\
0\end{array}$ & $\begin{array}{l}3 \\
1\end{array}$ & $\begin{array}{l}2 \\
0\end{array}$ & $\begin{array}{l}4 \\
2\end{array}$ & $\begin{array}{r}10 \\
3\end{array}$ & $30 \cdot 0$ \\
\hline $80-119$ & $\begin{array}{l}\text { T } \\
\mathbf{D}\end{array}$ & $\begin{array}{l}\mathbf{0} \\
\mathbf{0}\end{array}$ & $\begin{array}{l}2 \\
0\end{array}$ & $\begin{array}{l}1 \\
0\end{array}$ & $\begin{array}{l}\mathbf{0} \\
\mathbf{0}\end{array}$ & $\begin{array}{l}3 \\
0\end{array}$ & 0.0 \\
\hline $120+$ & $\begin{array}{l}\mathbf{T} \\
\mathbf{D}\end{array}$ & $\begin{array}{l}2 \\
0\end{array}$ & $\begin{array}{l}2 \\
0\end{array}$ & $\begin{array}{l}5 \\
1\end{array}$ & $\begin{array}{l}2 \\
2\end{array}$ & $\begin{array}{r}11 \\
3\end{array}$ & $27 \cdot 3$ \\
\hline All categories & $\begin{array}{l}\text { T } \\
\mathbf{D}\end{array}$ & $\begin{array}{r}20 \\
3\end{array}$ & $\begin{array}{r}16 \\
2\end{array}$ & $\begin{array}{r}22 \\
6\end{array}$ & $\begin{array}{l}32 \\
17\end{array}$ & $\begin{array}{l}90 \\
28\end{array}$ & \\
\hline Diseased $(\%)$ & 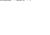 & 15.0 & $12 \cdot 5$ & $27 \cdot 3$ & $53 \cdot 1$ & & $31 \cdot 1$ \\
\hline
\end{tabular}

individuals as defined under "Methods" above varies in a random manner for all parameters tabulated except current cigarette-smoking category. In this category there was an increase in the prevalence of disease with increased cigarette consumption. These data were standardized by an indirect method so that the number of observed cases could be compared with the expected, assuming that the marginal rates for age or cigarette-smoking category applied to each group. A $\chi^{2}$ goodness-of-fit test was then applied under the hypothesis that the expected
TABLE 6

PREVALENCE OF CHRONIC NON-SPECIFIC RESPIRATORY DISEASE IN FEMALE FLAX-MILL WORKERS RELATED TO AGE AND SMOKING CATEGORY

\begin{tabular}{|c|c|c|c|c|c|c|c|}
\hline \multirow{2}{*}{$\begin{array}{l}\text { Current } \\
\text { Cigarette- } \\
\text { smoking } \\
\text { Category }\end{array}$} & & \multicolumn{4}{|c|}{ Age-group } & \multirow{2}{*}{$\begin{array}{c}\text { All } \\
\text { Cate- } \\
\text { gories }\end{array}$} & \multirow{2}{*}{$\begin{array}{c}\text { Diseased } \\
(\%)\end{array}$} \\
\hline & & $\mid 15-34$ & $35-44$ & $45-54$ & $55+$ & & \\
\hline Never smoked & $\begin{array}{l}\mathrm{T}^{*} \\
\mathrm{D} \dagger\end{array}$ & $\begin{array}{l}8 \\
0\end{array}$ & $\begin{array}{r}18 \\
1\end{array}$ & $\begin{array}{r}21 \\
4\end{array}$ & $\begin{array}{r}13 \\
1\end{array}$ & $\begin{array}{r}60 \\
6\end{array}$ & $10 \cdot 0$ \\
\hline Ex-smoker & $\begin{array}{l}\mathbf{T} \\
\mathbf{D}\end{array}$ & $\begin{array}{l}0 \\
0\end{array}$ & $\begin{array}{l}0 \\
0\end{array}$ & $\begin{array}{l}1 \\
0\end{array}$ & $\begin{array}{l}\mathbf{0} \\
\mathbf{0}\end{array}$ & $\begin{array}{l}1 \\
0\end{array}$ & $0 \cdot 0$ \\
\hline $1-20 /$ day & $\begin{array}{l}\mathbf{T} \\
\mathbf{D}\end{array}$ & $\begin{array}{l}0 \\
0\end{array}$ & $\begin{array}{l}1 \\
0\end{array}$ & $\begin{array}{l}5 \\
0\end{array}$ & $\begin{array}{l}\mathbf{0} \\
\mathbf{0}\end{array}$ & $\begin{array}{l}6 \\
0\end{array}$ & $0 \cdot 0$ \\
\hline$>20 /$ day & $\begin{array}{l}\mathrm{T} \\
\mathbf{D}\end{array}$ & $\begin{array}{l}0 \\
0\end{array}$ & $\begin{array}{l}2 \\
1\end{array}$ & $\begin{array}{l}1 \\
0\end{array}$ & 1 & $\begin{array}{l}4 \\
2\end{array}$ & $50 \cdot 0$ \\
\hline All categories & $\begin{array}{l}\text { T } \\
\mathbf{D}\end{array}$ & $\begin{array}{l}8 \\
0\end{array}$ & $\begin{array}{r}21 \\
2\end{array}$ & $\begin{array}{r}28 \\
4\end{array}$ & $\begin{array}{r}14 \\
2\end{array}$ & $\begin{array}{r}71 \\
8\end{array}$ & \\
\hline Diseased $(\%)$ & & 0.0 & $9 \cdot 5$ & $14 \cdot 3$ & $14 \cdot 3$ & & $11 \cdot 3$ \\
\hline
\end{tabular}

*Total. †Diseased (see text).

did not deviate significantly from the observed. Departure of observed from expected at a level of $\mathrm{p}<0.05$ was considered significant. Significant deviation was found only in respect to the smoking category. Age, years of dust exposure, or estimate of lifetime inhaled dust were not significantly related to the prevalence of disease. These data are summarized in Table 8 where the observed numbers of diseased persons for the various smoking categories are compared with the expected numbers when standardized for age, years of dust exposure, and estimated grams of dust inhaled. In one instance the deviation is significant $(0.05>p>0.02)$, and in the other two it is highly significant $(0.02>\mathrm{p}$ $>0.01$ ).

Thus in this group of males the effect of smoking far overshadows any effect due to age or occupational

TABLE 7

RESULTS OF ANALYSES OF AIR SAMPLES OBTAINED IN A FLAX MILL IN MASSACHUSETTS

\begin{tabular}{|c|c|c|c|c|c|c|c|c|}
\hline Area & $\begin{array}{l}\text { No. of } \\
\text { Samples }\end{array}$ & $\begin{array}{c}\text { Dust } \\
\text { Concentration } \\
\left.\text { (mg./m. } .^{3}\right) \\
\text { Mean (range) }\end{array}$ & $\begin{array}{c}\text { Mean } \\
\text { Particle } \\
\text { Size } \\
(\mu)\end{array}$ & 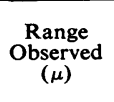 & $\begin{array}{c}\% \text { Mass in } \\
\text { Respirable } \\
\text { Size } \\
(<10 \mu)\end{array}$ & $\begin{array}{c}\text { Inorganic } \\
\text { Dust } \\
(\%)\end{array}$ & $\begin{array}{l}\mathrm{N}_{2} \text {-contain- } \\
\text { ing Organic } \\
\text { Trash } \\
(\%)\end{array}$ & $\begin{array}{c}\text { Cellulose } \\
(\%)\end{array}$ \\
\hline Repair & 2 & \multirow{10}{*}{$\begin{array}{c}24 \cdot 0 \\
(13 \cdot 3-34 \cdot 7) \\
13 \cdot 6 \\
(10 \cdot 3-16 \cdot 8) \\
2 \cdot 9 \\
(0 \cdot 6-5 \cdot 1) \\
2 \cdot 2 \\
(1 \cdot 5-2 \cdot 8) \\
2 \cdot 2 \\
(1 \cdot 4-3 \cdot 3) \\
1 \cdot 4 \\
(1 \cdot 2-1 \cdot 6) \\
0 \cdot 9 \\
(0 \cdot 8-1 \cdot 0) \\
0 \cdot 2 \\
(0 \cdot 1-0 \cdot 3) \\
0 \cdot 4 \\
(0 \cdot 2-0 \cdot 5) \\
\end{array}$} & $2 \cdot 0$ & \multirow[t]{2}{*}{$0.4-245.0$} & \multirow[t]{2}{*}{$<0.05$} & $7 \cdot 5$ & $14 \cdot 7$ & $77 \cdot 8$ \\
\hline Carding & 2 & & - & & & $19 \cdot 4$ & 15.5 & $65 \cdot 1$ \\
\hline Hackling & 4 & & $2 \cdot 1$ & $0.4-43.3$ & 16.00 & $7 \cdot 6$ & 14.0 & $78 \cdot 4$ \\
\hline Grading & 2 & & $3 \cdot 0$ & $0.4-245.0$ & $<0.05$ & 17.9 & $17 \cdot 7$ & 63.4 \\
\hline Preparation & 4 & & $1 \cdot 0$ & $0.4-165.2$ & $<0.05$ & $10 \cdot 6$ & $24 \cdot 2$ & $65 \cdot 2$ \\
\hline Spinning & 2 & & - & & & $14 \cdot 7$ & $13 \cdot 0$ & $72 \cdot 3$ \\
\hline Twisting & 2 & & - & & & - & - & - \\
\hline Saturation & 2 & & - & & & - & - & - \\
\hline \multirow[t]{2}{*}{ Warehouse } & \multirow[t]{2}{*}{2} & & \multirow[t]{2}{*}{-} & & & - & - & - \\
\hline & & & & & Mean & $13 \cdot 4$ & $17 \cdot 3$ & $69 \cdot 3$ \\
\hline
\end{tabular}


TABLE 8

PREVALENCE OF CHRONIC NON-SPECIFIC RESPIRATORY DISEASE IN MALE FLAX-MILL WORKERS OBSERVED NUMBERS IN VARIOUS SMOKING CATEGORIES COMPARED WITH EXPECTED NUMBER WHEN STANDARDIZED FOR AGE, YEARS OF DUST EXPOSURE, AND ESTIMATED GRAMS OF DUST INHALED

\begin{tabular}{|c|c|c|c|c|c|c|}
\hline \multirow{2}{*}{$\begin{array}{c}\text { Current } \\
\text { Cigarette-smoking } \\
\text { Category }\end{array}$} & \multirow[b]{2}{*}{ Total } & \multirow[b]{2}{*}{ Diseased $(\%)$} & \multirow{2}{*}{$\begin{array}{l}\text { Number } \\
\text { Observed }\end{array}$} & \multicolumn{3}{|c|}{ Number Expected Standardized for: } \\
\hline & & & & Age $\dagger$ & $\begin{array}{l}\text { Dust Exposure* } \\
\text { (years) }\end{array}$ & $\begin{array}{l}\text { Estimated Dust } \\
\text { Inhaled (g.) }\end{array}$ \\
\hline $\begin{array}{l}\text { Never smoked } \\
\text { Ex-smoker } \\
1-20 / \text { day } \\
>20 / \text { day } \\
\text { Total }\end{array}$ & $\begin{array}{l}20 \\
16 \\
22 \\
32 \\
90\end{array}$ & $\begin{array}{l}15 \cdot 0 \\
12 \cdot 5 \\
27 \cdot 3 \\
53 \cdot 1 \\
31 \cdot 1\end{array}$ & $\begin{array}{r}3 \\
2 \\
6 \\
17 \\
28\end{array}$ & $\begin{array}{r}6.47 \\
4.91 \\
6.55 \\
10.08 \\
28.01\end{array}$ & $\begin{array}{r}6 \cdot 05 \\
5 \cdot 07 \\
6 \cdot 57 \\
10 \cdot 32 \\
28.01\end{array}$ & $\begin{array}{r}6 \cdot 15 \\
4.75 \\
6.96 \\
10 \cdot 15 \\
28 \cdot 01\end{array}$ \\
\hline
\end{tabular}

Departure of observed from expected by $\chi^{2}$ goodness-of-fit test: ${ }^{*} 0.05>p>0.02 ; \uparrow 0.02>p>0.01$.

exposure to dusts. This, however, should not be interpreted that these factors may not have an effect in another population. Also the amount of dust exposure is low when the respirable amount of the dust in the air is taken into account. In the estimation of the amount of dust inhaled in a working lifetime it was assumed that all of the dust was inhaled and retained. It was presumed that this would correct for the earlier years of exposure when the amount of dust was probably greater than at present. The amount of dust in $\mathrm{mg} . / \mathrm{m}^{3}$ (Table 7) in the dustier operations was comparable to that seen by Goodall and Hardwick (1951) in British scutching factories. The dust concentrations in other areas in the plant were much lower than those noted by Goodall. The mean particle sizes were comparable in this study and the British study. Mair's data (Mair et al., 1960) from a batching operation in a jute mill show dust concentrations twice the levels seen here in the grading, preparation, or hackling areas.

There were considerable amounts of cellulose and organic trash in the dust. These components probably account for the larger dust particles, and the smaller particles are presumed to be primarily inorganic. In the British data quoted above, the ash residue or inorganic material amounted to 20 to $30 \%$ (Goodall and Hardwick, 1951) or $46 \%$ (Mair et al., 1960) of the total amount of dust collected. Here it was less and ranged from 7.6 to $19.4 \%$ of the total amount of dust collected.

That the exposure over the years has been low is further demonstrated by the observation of only two cases (one woman, 45 years of age, and one man, 46 years of age) who could possibly have had byssinosis. They did not have typical Monday symptoms but did complain of symptoms later in the week. Each had been exposed to the atmosphere of the mill for about 25 years. They had no breathlessness and their pulmonary function measurements were within normal limits. There is, however, suggestive evidence that there may be a selective process going on in this factory. For example, in the males there is an increase in the percentage of diseased persons over the first two decades. This is followed by a progressive fall in the next two older decades. This decrease in percentage of diseased individuals may represent a moving out of the mill of persons who had developed disease and who were made worse by the conditions there. If this were the case, then the byssinotics or those susceptible would not have been present at the time of the study.

Further evidence for the deleterious effect of smoking is shown in Table 9, where the average vital capacity as a percentage of the predicted is tabulated according to smoking category. Although the difference between the non-smoker group and the smoking group is not statistically significant there is a progressive trend, namely a fall in vital capacity, with increased smoking.

Similar comparisons for the effect of dust exposure or lifetime grams of dust inhaled showed no such trend. Also no such trend was noted in the women, probably because of the small number involved.

The mean physical characteristics and mean values of pulmonary function are presented in Table 10 for male and in Table 11 for female flax workers. The mean vital capacities by sex and agegroups are slightly lower than the predicted values. This in part results from these data being an average of three trials whereas the predicted values were the largest values of an unspecified number of trials (Miller et al., 1959). Furthermore, the predicted values came from a healthy population working in a hospital who could be expected to co-operate

TABLE 9 VITAL CAPACITY AS PERCENTAGE OF PREDICTED IN
MALE FLAX-MILL WORKERS IN RELATION TO CURRENT MALE FLAX-MILL WORKERS IN RELATION TO
CIGARETTE-SMOKING CATEGORY

\begin{tabular}{|c|c|c|c|}
\hline $\begin{array}{c}\text { Current } \\
\text { Cigarette-smoking } \\
\text { Category }\end{array}$ & $\begin{array}{l}\text { Number } \\
\text { of } \\
\text { Workers }\end{array}$ & $\begin{array}{c}\text { Mean Vital } \\
\text { Capacity as \% of } \\
\text { Predicted }\end{array}$ & $=\underbrace{\text { Standard }}_{\substack{\text { Deviation } \\
(\%)}}$ \\
\hline $\begin{array}{l}\text { Never smoked } \\
\text { Ex-smoker } \\
\text { 1-20/day } \\
>20 / \text { day }\end{array}$ & $\begin{array}{l}20 \\
16 \\
22 \\
32\end{array}$ & $\begin{array}{l}97 \cdot 0 \\
95 \cdot 5 \\
91 \cdot 3 \\
89 \cdot 3\end{array}$ & $\begin{array}{l} \pm 15 \cdot 22 \\
\pm 20.41 \\
\pm 16.31 \\
\pm 12.95\end{array}$ \\
\hline
\end{tabular}


TABLE 10

MEAN PHYSICAL CHARACTERISTICS AND MEAN AND STANDARD DEVIATION OF PULMONARY FUNCTION OF MALE FLAX-MILL WORKERS

\begin{tabular}{|c|c|c|c|c|}
\hline & \multicolumn{4}{|c|}{ Age-group } \\
\hline & $25-34$ & $35-44$ & $45-54$ & $55-64$ \\
\hline $\begin{array}{l}\text { No. of subjects* } \\
\text { Vital capacity (litres) }\end{array}$ & $\begin{array}{c}12 \\
4 \cdot 27 \\
( \pm 1 \cdot 51)\end{array}$ & $\begin{array}{c}10 \\
4 \cdot 39 \\
( \pm 1 \cdot 61)\end{array}$ & $\begin{array}{c}36 \\
3 \cdot 89 \\
( \pm 1 \cdot 02)\end{array}$ & $\begin{array}{c}29 \\
3 \cdot 70 \\
( \pm 1 \cdot 13)\end{array}$ \\
\hline $\begin{array}{l}\text { Vital capacity }(\% \text { of } \\
\text { predicted) } \\
\text { FEV }_{1 \cdot 0} \\
\text { FEV } 1: 0 \% \text { vital capacity } \\
\text { WPkV }+ \text { (litres/min.) }\end{array}$ & $\begin{array}{c}90 \cdot 3 \\
3 \cdot 78 \\
( \pm 1 \cdot 29) \\
88 \cdot 5 \\
546 \\
(+186)\end{array}$ & $\begin{array}{c}96 \cdot 9 \\
3 \cdot 58 \\
( \pm 1 \cdot 31) \\
81 \cdot 6 \\
543 \\
(+179)\end{array}$ & $\begin{array}{c}91 \cdot 0 \\
2 \cdot 85 \\
( \pm 0 \cdot 84) \\
73 \cdot 2 \\
477 \\
(+143)\end{array}$ & $\begin{array}{c}93 \cdot 2 \\
2 \cdot 68 \\
( \pm 0 \cdot 89) \\
72 \cdot 0 \\
441 \\
( \pm 145)\end{array}$ \\
\hline $\begin{array}{l}\text { WPkV (Higgins, 1957) } \\
\text { Age (years) } \\
\text { Height (in.) } \\
\text { Weight (lb.) }\end{array}$ & $\begin{array}{r}684 \\
29 \cdot 9 \\
67 \cdot 0 \\
155 \cdot 1\end{array}$ & $\begin{array}{l}586 \\
40 \cdot 2 \\
67 \cdot 0 \\
150 \cdot 4\end{array}$ & $\begin{array}{r}534 \\
49 \cdot 9 \\
66 \cdot 6 \\
162 \cdot 6\end{array}$ & $\begin{array}{l}475 \\
59 \cdot 4 \\
66 \cdot 3 \\
167 \cdot 4\end{array}$ \\
\hline
\end{tabular}

*Two workers in age group 15-24, and one $65+$ are not included. †WPkV $=$ Wright peak flow meter.

better than a general working group, and cigarette smokers with a persistent cough were excluded.

The FEV $_{1.0}$ expressed as a percentage of the vital capacity decreased with age in both men and

TABLE 12

PERCENTAGE OF POSITIVE RESPONSES TO VARIOUS QYESTIONS AS SELECTED BY FLETCHER et al. (1959), MASSACHUSETTS

\begin{tabular}{|c|c|c|c|c|c|c|c|}
\hline \multirow{3}{*}{\multicolumn{2}{|c|}{ Question No. }} & \multicolumn{6}{|c|}{$\%$ Positive Replies } \\
\hline & & \multicolumn{3}{|c|}{ Men } & \multicolumn{3}{|c|}{ Women } \\
\hline & & $\begin{array}{c}35-44 \\
(10)\end{array}$ & $\begin{array}{c}45-64 \\
(65)\end{array}$ & $\begin{array}{l}\text { Total } \\
(75)\end{array}$ & $\begin{array}{c}35-44 \\
(21)\end{array}$ & $\mid \begin{array}{c}45-64 \\
(42)\end{array}$ & $\begin{array}{l}\text { Total } \\
\text { (63) }\end{array}$ \\
\hline \multirow{4}{*}{$\begin{array}{l}1 . \\
2 . \\
2 \\
4 \\
6 . \\
7 . \\
7 \\
9 \\
17 .\end{array}$} & \multirow{4}{*}{$\begin{array}{l}\text { Cough usually } \\
\text { Cough winter a.m. } \\
\text { Cough winter a.m. } \\
\text { and during day } \\
\text { Phlegm usually } \\
\text { Phlegm winter a.m. } \\
\text { Phlegm winter a.m. } \\
\text { and during day } \\
\text { Dyspnoea: }\end{array}$} & $\begin{array}{l}50 \\
10\end{array}$ & $\begin{array}{l}27 \cdot 7 \\
23 \cdot 1\end{array}$ & $\begin{array}{l}30 \cdot 7 \\
21 \cdot 3\end{array}$ & $\begin{array}{c}9 \cdot 5 \\
4 \cdot 8\end{array}$ & $\begin{array}{l}11.9 \\
11.9\end{array}$ & $\begin{array}{r}10 \cdot 9 \\
9 \cdot 5\end{array}$ \\
\hline & & 0 & $7 \cdot 7$ & $6 \cdot 7$ & 0 & $4 \cdot 8$ & $3 \cdot 2$ \\
\hline & & & $\begin{array}{l}21 \cdot 6 \\
15 \cdot 4\end{array}$ & $\begin{array}{l}21 \cdot 3 \\
18 \cdot 7\end{array}$ & $\begin{array}{l}9 \cdot 5 \\
9 \cdot 5\end{array}$ & $\begin{array}{r}9 \cdot 5 \\
11 \cdot 9\end{array}$ & $\begin{array}{r}9 \cdot 5 \\
11 \cdot 1\end{array}$ \\
\hline & & 10 & $3 \cdot 1$ & $4 \cdot 0$ & $4 \cdot 8$ & $2 \cdot 4$ & $3 \cdot 2$ \\
\hline & $\begin{array}{r}\text { Dyspnoea: } \\
\text { Grade } 1 \\
2 \\
3 \\
4 \text { and } 5 \\
\text { Wheezing only with }\end{array}$ & $\begin{array}{r}100 \\
0 \\
0 \\
0\end{array}$ & \begin{tabular}{|c|}
$93 \cdot 8^{*}$ \\
1.5 \\
0 \\
1.5
\end{tabular} & $\begin{array}{c}94 \cdot 7 \\
1 \cdot 3 \\
0 \\
1 \cdot 3\end{array}$ & $\begin{array}{r}100 \\
0 \\
0 \\
0\end{array}$ & $\begin{array}{c}95 \cdot 0 \dagger \\
2 \cdot 5 \\
0 \\
0\end{array}$ & $\begin{array}{c}96 \cdot 8 \\
2 \cdot 1 \\
0 \\
0\end{array}$ \\
\hline & $\begin{array}{l}\text { Wheezing only with } \\
\text { colds } \\
\text { Wheezing }\end{array}$ & 10 & $27 \cdot 7$ & $25 \cdot 3$ & $28 \cdot 6$ & $21 \cdot 4$ & $23 \cdot 8$ \\
\hline 23. & $\begin{array}{c}\text { occasionally } \\
\text { Wheezing most days }\end{array}$ & $\mathbf{0}$ & $12 \cdot 3$ & $10 \cdot 7$ & $4 \cdot 8$ & $7 \cdot 1$ & $6 \cdot 4$ \\
\hline & $\begin{array}{l}\text { and nights } \\
\text { Colds to chest: }\end{array}$ & 0 & $1 \cdot 5$ & $1 \cdot 3$ & 0 & 0 & 0 \\
\hline & $\begin{array}{c}<3 \text { years } \\
>3 \text { years } \\
\text { Weather affects }\end{array}$ & $\begin{array}{r}30 \\
0\end{array}$ & $\begin{array}{r}4 \cdot 6 \\
10 \cdot 8\end{array}$ & $\begin{array}{l}8 \cdot 0 \\
9 \cdot 3\end{array}$ & $\begin{array}{l}4 \cdot 8 \\
0\end{array}$ & $\begin{array}{l}2 \cdot 4 \\
7 \cdot 1\end{array}$ & $\begin{array}{l}3 \cdot 2 \\
4 \cdot 8\end{array}$ \\
\hline & chest & 10 & $9 \cdot 2$ & $9 \cdot 3$ & $9 \cdot 5$ & $7 \cdot 1$ & ' \\
\hline $\begin{array}{l}41 . \\
42 .\end{array}$ & $\begin{array}{l}\text { Nasal catarrh winter } \\
\text { Nasal catarrh }\end{array}$ & 20 & $9 \cdot 2$ & 10.7 & $19 \cdot 0$ & $9 \cdot 5$ & 12 \\
\hline & & 20 & $4 \cdot 6$ & 6.7 & $23 \cdot 8$ & 11.9 & 15 \\
\hline 43. & $\begin{array}{l}\text { Chest illness once } \\
\text { Current smoking } \\
\text { category: }\end{array}$ & 10 & $5 \cdot 3$ & $6 \cdot 7$ & $\mathbf{0}$ & $7 \cdot 1$ & $4 \cdot 8$ \\
\hline & Non-smoker & 30 & $20 \cdot 0$ & 21.4 & $85 \cdot 7$ & $81 \cdot 0$ & $82 \cdot 5$ \\
\hline & $\begin{array}{l}\text { Ex-smoker } \\
\text { Smoker }\end{array}$ & $\begin{array}{l}20 \\
50\end{array}$ & $\begin{array}{l}21 \cdot 5 \\
58 \cdot 5\end{array}$ & $\begin{array}{l}21 \cdot 4 \\
56 \cdot 2\end{array}$ & $\begin{array}{c}0 \\
14 \cdot 3\end{array}$ & $\begin{array}{r}2 \cdot 3 \\
16 \cdot 7\end{array}$ & $\begin{array}{r}1.6 \\
15 \cdot 9\end{array}$ \\
\hline
\end{tabular}

*3. $1 \%$ physical disability in addition

$\lceil 2.5 \%$ physical disability in addition.
TABLE 11

MEAN PHYSICAL CHARACTERISTICS AND MEAN AND STANDARD DEVIATION OF PULMONARY FUNCTION OF FEMALE FLAX-MILL WORKERS

\begin{tabular}{|c|c|c|c|c|}
\hline & \multicolumn{4}{|c|}{ Age-group } \\
\hline & $25-34$ & $35-44$ & $45-54$ & $55-64$ \\
\hline $\begin{array}{l}\text { No. of subjects* } \\
\text { Vital capacity (litres) }\end{array}$ & $\begin{array}{c}7 \\
3 \cdot 18 \\
( \pm 1 \cdot 41)\end{array}$ & $\begin{array}{c}21 \\
3 \cdot 24 \\
( \pm 0 \cdot 77)\end{array}$ & $\begin{array}{c}28 \\
2 \cdot 77 \\
( \pm 0.75)\end{array}$ & $\begin{array}{c}14 \\
2.48 \\
( \pm 0.90)\end{array}$ \\
\hline $\begin{array}{l}\text { Vital capacity }(\% \text { of } \\
\text { predicted }) \\
\text { FEV }_{1 \cdot 0}\end{array}$ & $\begin{array}{c}95 \cdot 8 \\
2 \cdot 75 \\
(+1 \cdot 29)\end{array}$ & $\begin{array}{c}99 \cdot 1 \\
2 \cdot 74 \\
(+0.65)\end{array}$ & $\begin{array}{c}88 \cdot 5 \\
2 \cdot 26 \\
(+0.62)\end{array}$ & $\begin{array}{c}82 \cdot 8 \\
1.96 \\
(+0.79)\end{array}$ \\
\hline $\begin{array}{l}\text { FEV }_{1: 0} \% \text { Vital capacity } \\
\text { WPkṾ̛ (litres/min.) }\end{array}$ & $\begin{array}{l}( \pm 1 \cdot 29) \\
871 \\
( \pm 173)\end{array}$ & $\begin{array}{l}89 \cdot 6 \\
403 \\
(+107)\end{array}$ & $\begin{array}{l}81 \cdot 6 \\
340 \\
(+103)\end{array}$ & $\begin{array}{l}79 \cdot 0 \\
292 \\
( \pm 118)\end{array}$ \\
\hline $\begin{array}{l}\text { WPkV (Higgins, 1957) } \\
\text { Age (years) } \\
\text { Height (in.) } \\
\text { Weight (lb.) }\end{array}$ & $\begin{array}{r}431 \\
32 \cdot 3 \\
62 \cdot 3 \\
134 \cdot 4\end{array}$ & $\begin{array}{l}388 \\
40 \cdot 7 \\
62 \cdot 35 \\
143 \cdot 4\end{array}$ & $\begin{array}{r}364 \\
48 \cdot 5 \\
61 \cdot 7 \\
143 \cdot 4\end{array}$ & $\begin{array}{r}297 \\
58 \cdot 5 \\
61 \cdot 3 \\
150 \cdot 3\end{array}$ \\
\hline
\end{tabular}

* One worker, 19 years, not included.

$+W P k \dot{V}=W r i g h t$ peak flow meter.

All standard deviations have been calculated using small numbers correction.

women. The values tended to be lower in the men. This did not appear to be due to low vital capacities in the female group since the vital capacities, especially in the younger ones, were closer to the predicted values than in the males. The greater fall in the $\mathrm{FEV}_{\mathbf{1 . 0}}$ in the older men is probably more related to the prevalence of respiratory disease in this group and in particular to their greater cigarette consumption.

The Wright peak-flow meter values fall with age as was seen by Higgins (1957) in a survey of an agricultural population. His values corrected as specified in his paper are included. In the men the British values are higher whereas in the women they appear to be similar. This difference cannot be explained on the basis of difference in height since this group tended to be taller than Higgins' group. A further comparison with British data is possible by means of Table 12 where the percentage of positive replies to various questions selected by Fletcher et al. (1959) are listed. The age-groups are not identical, but the inclusion of an older group should tend to weight the results towards more disease. In this and in the British report there is the same percentage of positive replies in the men to question one: "Do you usually have a cough?" It is lower in the American women. In all the other questions there are fewer positive responses in the American group than in the British, despite the fact that the percentage of "diseased" individuals in the American group as defined under "Methods" above is 31.1 for men and 11.3 for women. This probably indicates that, in the male group where there is a significant amount of "disease", there are many with relatively mild chronic non-specific respiratory disease whereas in Great Britain there is a greater 
proportion with more extensive chronic non-specific respiratory disease.

More specific studies are necessary to define the relative importance of occupational exposures to dusts and gases, air pollution, and previous respiratory infections. From this study cigarette smoking appears to be one of the more important factors in the production of chronic non-specific respiratory disease as suggested by Palmer (1954) and Oswald and Medvei (1955).

To answer these questions and to ascertain the relative effectiveness of dust or gas exposures at work future studies should concentrate on large numbers of non-smokers. This will eliminate the overwhelming contribution of cigarette smoking.
The authors gratefully acknowledge the co-operation of the Ludlow Corporation and of the workers at the mill at Ludlow who made this study possible.

\section{REFERENCES}

Fairbairn, A. S., Wood, C. H., and Fletcher, C. M. (1959). Brit. J.

Fletcher, C. M., Elmes, P. C., Fairbairn, A. S., and Wood, C. H.

(1959). Brit. med. J., 2, 257 . (1951). Brit. J. industr. Med., 8, 161.

Higgins, I. T. T. (1957). Brit. med. J., 2, 1198 Mair, A., Smith, D. H., Wilson, W. A., and Lockhart, W. (1960).

Miller, W. F. Johnson, R. L., Jr., and Wu, N. (1959). J. appl. Physiol., $14,157$.

Oswald, N. C., and Medvei, V. C. (1955). Lancet, 2, 843.

Palmer, K. N.' V. (1954). Brit. med. J., 1, 1473.

Pemberton, J. (1956). A.M.A. Arch. industr. Hith., 13, 529.

Pemberton, J. (1956). A.M.A. Arch. industr. Hith., 13, 529. 1213. Reid, D. D. (1960). Amer. J. publ. Hith, 50, No. 6, Suppl. 2, p. 53. Reid, D. D. (1960). Amer. J. publ. Hith, 50,

Silverman, L., and Viles, F. J., Jr. (1950). Textile Res. J., 20, 109. 